\title{
Gusdurians' Environmental Advocacy, Cultural Politics and Humanity in the Pandemic Era
}

\author{
Sukirman $^{1 *}$, and Muhammad Abdullah ${ }^{2}$ \\ ${ }^{1}$ Master of Literature Department of Indonesian Literature, Faculty of Humanities, Diponegoro \\ University, Semarang - Indonesia \\ ${ }^{2}$ Master of Literature Department of Indonesian Literature, Faculty of Humanities, Diponegoro \\ University, Semarang - Indonesia
}

\begin{abstract}
The younger generation in the Gusdurian network believed from generation to generation that Gus Dur's ideology was suitable to be applied to conditions in Indonesia which were intolerant of cultural and religious diversity as well as the social environment. The manifestation of this ideology is preserved through discussion forums, peaceful actions, books, caring actions, and criticism of the sovereign government. This article will describe to what extent the role of the Gusdurian community in carrying out social care actions during the pandemic. This research uses cultural theory. The writing method used is descriptive qualitative with literature studies related to culture, humanity, and other research about Gusdurian. The results of this study indicate that during a pandemic, the strength of the community is an important factor in strengthening the mentality of the community in dealing with disaster. The Gusdurian network that is spread throughout Indonesia has the power to raise aid and at the same time distribute it to various regions. This has become strategic as a social care moral movement to deal with disasters.
\end{abstract}

\section{Introduction}

Gusdurian Network is a synergy arena for Gusdurian in cultural and nonpractical political space. The network consists of individuals, communities/local forums, and organizations are inspired by Gus Dur's values, thoughts, and struggles. Because it is in the form of a working network, it does not need formal membership. Gusdurian network focuses on the synergy of nonpractical political work on several dimensions occupied by Gus Dur, consisting of 4 big dimensions: Islam and faith, culture, nation, and humanity [1].

The core of Gusdurian Network lies in Gus Dur's value, thoughts, and struggle that still conserved and guards Indonesia's nationality movement; through the synergy of his followers' work, based on Gus Dur's nine values: a unity of God, humanity, justice, equality, liberation, brotherhood, simplicity, chivalrous stance, and traditional wisdom. Gusdurian Network spread all over Indonesia and also abroad. In various place, some local community was formed, but most of it connected by forum and work dialogue. Gusdurian's young generation drove the rise of the local Gusdurian community (the 2000s), excited to gather, study and exemplify Gus Dur's values. There are more than 100 Gusdurian local communities until late 2020.

\footnotetext{
* Corresponding author: kirmankiral@gmail.com
} 
Farida (2016) previous study "Strategi Eksistensi Komunitas Jaringan Gusdurian Jombang" shows the Gusdurian communication strategy in media, particularly in social media. Another research is connecting Gusdurian and Islam religiosity. The update of this research is about Gusdurian community participation and power in times of pandemic by using a cultural approach.

\section{Writing Method}

A writer using the descriptive qualitative method with library study of culture, environment, pandemic and other research about Gusdurian. The library study consists of the article, books, and annual report about Gusdurian. This article is updated with culture theory to analyze the object of research: Gus Dur ideology by the Gusdurian, connected with network, culture, and environment in the time of pandemic in Indonesia.

\section{Discussion}

Alissa Wahid emphasized that the Gusdurian act focuses on Gus Dur's thoughts, not an individual cult. She stated, "His family does not own Gus Dur, but already owned by international society." Today, Gus Dur follower focuses on implementing thoughts concepts in culture, education, and economy to be natural movement in society to benefit many people in Indonesia in time of the pandemic.

Gusdurian Network describes Gusdurian as Gus Dur's ideologic children who have extraordinary commitment to continue Gus Dur's dreams, including dream to portray Islam as friendly and tolerant, fighting for humanity and justice. Of course, Gusdurian is not limited to Islam groups. Gus Dur is beyond the religious border, inviting various religious groups to take part in this movement. Gusdurian Network is a social and cultural movement that "into Gus Dur thoughts, exemplify his character and value principles, and continuing Gus Dur struggle according to time development challenge." Since it was established in 2010, they have kept on finding an ideal form to avoid formalism. Gusdurian movement ordained itself as a movement that represented the spirit of Islam Nusantara [2].

Since it was established in 2010, the Gusdurian movement has been present in handling social, economic, and cultural problems that experience anomaly due to fundamentalism current in society. Gusdurian movement presents in peace campaign and defends minority groups rights. In 2013, all Gusdurian network knots in various cities such as Yogyakarta, Samarinda, Tegal, Malang, Jombang, Bondowoso, Temanggung, Indramayu, and other cities simultaneously gave peaceful Christmas message. They set up banners and billboards to deliver Merry Christmas's messages to all Christian. The banner and billboard were set up in strategic places to convey religious toleration.

Peace Chrismast Campaign confirms Gusdurian commitment in the middle of resistance and attack toward churches in Indonesia. This is also a realization of Gusdurin's commitment in terms of toleration. In the middle of the Islam fundamentalism movement, the Gusdurian movement proclaims a world toleration day memorial. On November 16th, 2013, the Gusdurian network in Bogor and other cities held a sympathetic act and gave away stickers and flyers of Gus Dur's quotes about peace. This displayed the commitment of the movement toward toleration and peace. When almost all Islam groups resisted Syiah, Gusdurian facilitated Sampang Syiah refugees to ride old bicycles and go to President's palace. Gusdurian movement also presents several rejection cases on Sapta Darma follower's funerals in Brebes and other places in Central Java. And many more.

In terms of social concern, Gusdurian is undoubtedly committed. Taken from the website gusdurianpeduli.org, Gusdurian stated that they have a Gusdurian Care unit that focused more on Gus Dur's values in humanity. This foundation administers Gusdurian Network in fast disaster response, social and economic empowerment, and volunteer organizing. This includes many activities during covid 19 pandemic in Indonesia since 2020.

Gusdurian Care has done the actual act in every social activity, including in times of 
pandemic. Covid 19 pandemic urge government to act fast. Hundreds of million Indonesian citizens spread in numerous islands became obstacles in distributing help and other things related to pandemics. When several countries held a lockdown, Indonesia applied a stay-athome policy, social distancing, and mask use. Religious leaders delivered instruction not to hold any ceremony that is potentially grouping lots of people. In the beginning, the policy becomes controversial. However, in the end, several religious leaders with plural points of view give a more explicit statement, so religious ceremonies become private, at home, and using technology.

Peace Chrismast Campaign confirms Gusdurian commitment in the middle of resistance and attack toward churches in Indonesia. This is also a realization of Gusdurin's commitment in terms of toleration. In the middle of the Islam fundamentalism movement, the Gusdurian movement proclaims the world toleration day memorial. On November 16th, 2013, the Gusdurian network in Bogor and other cities held a sympathetic act and gave away stickers and flyers of Gus Dur's quotes about peace. This displayed the commitment of the movement toward toleration and peace. When almost all Islam groups resist Syiah, Gusdurian facilitates Sampang Syiah refugees to ride old bicycles and go to President's palace. Gusdurian movement also presents several rejection cases on Sapta Darma follower's funerals in Brebes and other places in Central Java. And many more.

In terms of social concern, Gusdurian is undoubtedly committed. Taken from the website gusdurianpeduli.org, Gusdurian stated that they have a Gusdurian Care unit that focused more on Gus Dur's values in humanity. This foundation administers Gusdurian Network in fast disaster response, social and economic empowerment, and volunteer organizing. This includes many activities during covid 19 pandemic in Indonesia since 2020.

Gusdurian Care has done the actual act in every social activity, including in times of pandemic. Covid 19 pandemic urge government to act fast. Hundreds of million Indonesian citizens spread in numerous islands became obstacles in distributing help and other things related to the pandemic. When several countries held a lockdown, Indonesia applied a stay-athome policy, social distancing, and mask use. Religious leaders delivered instruction not to hold any ceremony that potentially grouped lots of people. In the beginning, the policy becomes controversial. However, in the end, several religious leaders with plural points of view give a more explicit statement, so religious ceremonies become private, at home, and using technology.

Our society has endured many things such as colonialism, tsunami, earthquake, flood, slides, etc. When the government is still making social aid policy, society has already made moves to give away social aid. A collaborative work culture passed down from generation to generation still lives in lower-class society nowadays. They do not need any birocratic reason, the spirit to help others without ulterior motives through various media such as village institution, mosque, zakat agency, and online platform is guiding them to do social movement to help other in time of the pandemic. Aid from civilians to those who suffer due pandemics can give a solution when the stay-at-home policy is applied and has a risk of work termination.

Lifestyle is switched from face-to-face activity to stay-at-home activity. Gusdurian solidarity and bond make it easier to aid society because Gusdurian Network is already formed in many regions in Indonesia. \#salingjagahadapicorona is a movement made by Gusdurian to give economic aid to those who suffer from the covid 19 pandemic. This group gives away aid such as masks, gloves, hand sanitizer, and self-protection tools. Gusdurian distributed this aid to poor people such as labor, informal worker, and others. They work together with various parties to hold fundraising.

When the government dealt with limitations in providing medical tools and its infrastructure, civilians helped each other. Muhammadiyah religious leaders give 65 Muhammdiyah hospitals and Aisyiyah as the reference of covid 19 handling. Gusdurian Care has distributed 24.000 aid packages for more than 100.000 people all around Indonesia and 1.000 aid packages to Indonesian workers in Malaysia. Universities also hand in hand to help to handle covid 19. Civilians spread information and free consultation regarding covid 19 through online media. This shows that civilian movement with collaborative work culture can 
set aside religion and race sentiment and enable them to deal with pandemics and other crises. Gusdurian.net recorded that Indonesia is one of the highest social and civilian participation in the world. This has become a tremendous start in handling many kinds of problems in Indonesia.

Workshop and discussion switched from face to face into online. Gusdurian sees that creative activities can help the economy. One of the activities is creating an online entrepreneurship workshop. Gusdurian sees creative activity needed as a survival strategy in a time of the pandemic. Society needs to be educated about online business strategy, so they will not be stuck on conventional business forms. Discussion held with famous business people and motivators such as Yuswohady and many others.

At the same time, Gusdurian Network builds synergy to communicate and stay alert on potential terror acts to help set a conducive environment in time of the pandemic. Lots of hoaxes regarding pandemics could mislead into false information and tendency to blame the government. This pandemic was used by several parties to split up our nation and bring up disputes among people. People's trust toward the government has become a significant factor in handling the covid 19 pandemic. The spirit of toleration culture of Gusdurian become an essential factor that relevant to the condition. Various activities are held, such as discussion, literacy, and election of peace ambassadors to keep harmony among religious and social relationships. Gusdurian pluralism spirit has crossed race and religious border, issues that still become significant problems in Indonesia nowadays. Gusdurian presents to conserve Gus Dur's ideology in all situations.

\section{Conclusion}

Gusdurian Movement has proven to be a basic knot to keep tolerant Indonesian Islam, guarding peace, justice, and humanity. Moreover, this movement can also maintain harmonization of Indonesian Islam that is tolerant, inclusive, and moderate. This is not easy. Gusdurian struggle amid spiritual ambition that tends to become intolerant has been explained in an early article. Besides that, political conditions that often mix personal and group benefits become one of the biggest obstacles in this struggle. Gusdurian regeneration needs to be done continually as an alternative to equalize Indonesia's democratic life.

Covid 19 pandemic strike in a way that no country can fully handle, including Indonesia, communal work spirit, toleration, and pluralism become vital elements to build nation mentality to deal with all kinds of situations. In this term, Gusdurian has been proven tested. Pandemic time is crucial in social, health, mental, and so many other things. It is essential that in the pandemic, we need to stop hoaxes or hate speech and bring back trust to the government to handle the pandemic. The power of groups and societies that care about social benefit becomes vital in aiding solutions for all problems. It is more potential if the network is already built and has roots from many years back. Gusdurian, that accepted by various religious groups become a lighter to social economy power in dealing with covid 19 pandemic. The Gusdurian network can solve aid distribution problems all over Indonesia to minimize this problem.

Proper appreciation needs to be given to Gus Dur ideology children wherever they are. This includes moderate Islam groups such as Nahdlatul Ulama (NU) and Muhammadiyah that also invested in our religious situation right now. Although they are not joining those two groups, proper appreciation also needs to be given to other groups that agreed, spread, and conserved Gus Dur's concept and thoughts. All society elements need to hand in hand keeping the religious spirit in Islam dreams as mentioned before. The Gusdurian movement has proven to be an essential knot to keep tolerant Indonesian Islam, guarding peace, justice, and humanity.

Moreover, this movement can also maintain harmonization of Indonesian Islam that is tolerant, inclusive, and moderate. This is not easy. Gusdurian struggle amid spiritual ambition that tends to become intolerant has been explained in an early article. Besides that, political conditions that often mix personal and group benefits become one of the biggest obstacles in this struggle. Gusdurian regeneration needs to be done continually as an 
alternative to equalize Indonesia’s democratic life.

\section{References}

1. Gusdurian. Buku Saku Jaringan Gusdurian, Seknas Jaringan Gusdurian, Yogyakarta (2013).

2. Alisjahbana, Sutan Takdir. The Concept of Culture and Civilization: Probem of National Identity and The Emerging World in Anthropology and Sociology, Dian Rakjat, Jakarta (1989).

3. Koentjoroningrat. Pengantar Ilmu Antropologi, Rineka Cipta, Jakarta (2000).

4. Ihromi. Pokok-Pokok Antropologi Budaya, Yayasan Obor Indonesia, Jakarta (2006).

5. M. Suhbi Azhari (koord.Penulis). Laporan Akhir Tahun Kebebasan Beragama dan Intoleransi, The Wahid Institute, Jakarta (2012). 